\title{
STUDIES ON FLOWERING, FRUITING AND RESIDUAL EFFECT OF SOME BREAKING DORMANCY AGENTS ON TWO PLUM CULTIVARS
}

\author{
MOHAMED, AZZA I. ${ }^{1}$ and HEND A. MOHAMED ${ }^{2}$
}

1. Horticulture Res. Institute, ARC, Giza -Egypt.

2. Centeral Agricultural Pesticides Laboratory, ARC, Giza -Egypt.

(Manuscript received 6 December 2016)

\begin{abstract}
$\mathrm{T}$ his study was conducted during 2014 and 2015 seasons to compare the effect of spraying dormancy-breaking agents Dinitro-O-Cresol (DNOC) in the form of Universal oil at two concentrations (5\% and at 6\%);Duromix (which contains $50 \%$ Hydrogen cyanamide) at $1 \%+$ Mineral oil at $1.5 \%$; Thiourea at $1.5 \%+$ Mineral oil at $1.5 \%$; Light mineral oil at 2\% [CAPL2] and a control treatment, at mid-January, in two seasons, on flowering; fruiting and detecting the residual effect of breaking agents on Hollywood and Beauty plum cultivars. Measurements included chilling requirements; dates of different stages of flower bud opening; flower bud opening percentages; fruit set percentages; heat requirements; dates of fruit maturity; yield; fruits physical and chemical properties and the residual of breaking agents in fruits. Results indicated that calculating chilling hours using temperature at $10.0{ }^{\circ} \mathrm{C}$ or below was more suitable than temperature at or below $7.2{ }^{\circ} \mathrm{C}$ or $15.0{ }^{\circ} \mathrm{C}$. Application of all dormancy breaking agents had advanced fruit set stage which ranged from 17 to 21 days for the two cultivars. Universal oil at $6 \%$ and Duromix at $1 \%$ + Mineral oil at $1.5 \%$ treatments gave the highest fruit set percentages of the two cultivars. Meanwhile, Uinversal at $5 \%$ and Duromix at $1 \%+$ Mineral oil at $1.5 \%$ treatments gave the highest percentages of fruit set of Beauty cultivar. Uinversal at $6 \%$ had the lowest accumulated growing degree days from time of flower bud break till fruit maturity in Hollywood cultivar. Uinversal at $6 \%$ had the highest yield weight per tree in Hollywood and Beauty cultivars. Uinversal at $5 \%$; Uinversal at $6 \%$ and Duromix at $1 \%+$ Mineral oil at $1.5 \%$ had the earliest fruit maturation of the two cultivars. Uinversal at $6 \%$ and Duromix at $1 \%+$ Mineral oil at $1.5 \%$ treatments significantly increased fruit size; weight and diameter of the two cultivars. There were no agent residues found in fruits in the two cultivars 110 days from after application. It can be recommended that Dinitro-O-Cresol at $6 \%$ and Duromix at $1 \%+$ Mineral oil at $1.5 \%$ were the best dormancy-breaking agents application on Hollywood and Beauty cultivars .Moreover, it is safely compounds to use.
\end{abstract}

Dormancy-breaking agents, Dinitro-O-Cresol\{Universal oil\}, Duromix \{Hydrogen cyanamide\}, Thiourea, Light mineral oil [CAPL2] , residual effect. 


\section{INTRODUCTION}

Plum tree remains in dormancy during December and January and Bud break takes place from the first week of February after completing the chilling requirements. Prevailing weather conditions during the whole crop growing season have direct bearing upon the phonological events of the crop which ultimately affected the crop yield. The duration of each growth phase is a result of crop response to external environmental factors [Dwyer and Stewart (1986)]. Using of rest-breaking chemicals led us to look for alternatives to long-used chemicals such as Dinitro-O-Cresol(DNOC) that in combination with oil is still used in Israel to break bud rest of deciduous fruit trees [Erez et al., (1993)]. Treatment of El-dorado plum trees with dormex, thiourea, Krestalon (A compound fertilizer), thiourea +Krestalon terminated winter dormancy, accelerated flowering and vegetative bud break and increased the percentage of bud break, fruit set and yield with the Dormex treatment being the most effective Shahin et al., (1997). Meanwhile, krisanapook and Subhadrabandhu (1993) mentioned that high concentration of hydrogen cyanamide was toxic as noticed by dried dead shoots. North (1993) indicated that cyanamide, a powerful rest - breaking agent on a range of fruit kinds, may replace DNOC/oil in the short-term, but acute toxicity symptoms limit its mediumterm acceptance. Attempts to reduce its concentration without compromising efficacy by the dual application of other agents has been investigated. Although mineral oils have long been known as rest-breaking agents, new and registered oil products applied alone and in conjunction with other potential substances have shown promise.

Therefore, this investigation was carried out to compare the effect of spraying dormancy- breaking agents universal oil (at two concentrations $5 \%$ and $6 \%$ ); Duromix at $1 \%+$ mineral oil at $1.5 \%$; Thiourea at $1.5 \%+$ Mineral oil at $1.5 \%$ and Light mineral oil at $2 \%$ in addition to the control on chilling requirements ;opening date ;opening percentages of vegetative and flower bud ; fruit set percentages; heat requirements ; dates of fruit maturity ; yield and fruit physical and chemical properties of two plum cultivars Hollywood and beauty. Also, detecting the residual effect of dormancybreaking agents in fruits.

\section{MATERIALS AND METHODS}

The present investigation was carried out during two successive seasons of 2014 and 2015 to study the effect of some breaking agents on flowering, fruiting and residual effect on "Hollywood" and "Beauty" plum cultivars (Prunussalicina.) in a private orchard at Khatatba region, Menofia Governorate. The trees were eight years old plum 
cultivars budded on Mariana plum rootstock. Trees were planted at $5 \mathrm{~m}$ apart, and grown in a clay soil under flood irrigation system.

Eighteen trees in each cultivar as far as possible uniform in size and vigor were chosen and treated with breaking agents at mid-January in two seasons.

Dormancy breaking agents used in this study were:-

1- Dinitro-O-Cresol (DNOC) in the form of Universal oilts 5\%.

2- Dinitro-O-Cresol (DNOC) at 6\%.

3- Thiourea at $1.5 \%+$ mineral oil at $1.5 \%$.

4- Hydrogen Cyanamid (Duromix) at $1 \%+$ mineral oil at $1.5 \%$.

5- Light mineral oil (in the form CAPL2) at $2 \%$.

6- Control (Untreated trees).

A complete randomized block design with 3 replicates was used. The following determinations were measured:-

\section{A - Chilling and heat requirements:-}

Data degrees of temperature were obtained from the central laboratory for Agricultural climate [CLAC] all year around by means of a hygrothermogragh, (model H 311 weather Measure Corporation) in a weather shelter, placed $1.5 \mathrm{~m}$ above ground.

\section{A. I. Determination of chilling requirement:-}

In each season, temperatures were recorded every 1 hour all year around. Calculation of chilling hours started in late fall when temperature dropped to $15^{\circ} \mathrm{C}$ (Dec., 2014 and Dec., 2015). The termination of vegetative bud was determined when about $50 \%$ of total number of buds took the pyramidal shape. On the other hand, the chilling termination of flower bud was determined when about $50 \%$ of the total number of buds took the dome shape.

Chilling requirements of vegetative and flower buds were calculated as follows:

Total hours at or below $7.2^{\circ} \mathrm{C}, 10.0^{\circ} \mathrm{C}$ and $15.0^{\circ} \mathrm{C}$ were recorded according to Weinberger (1950), Gilreath and Buchaman (1981), Sherman and Lyrene (1989), respectively.

\section{A. 2. Heat units:-}

Heat units were calculated at the moment of chilling termination until maturity of fruit. Different stages of flower bud development (bud swell, complete flowering, petal fall and fruit set) until fruit maturity, in relation to accumulated heat units at each defined stage, were determined for each treatment and cultivar.

Heat units in terms of growing degree days (GDD) from the predicted time of dormancy completion until fruit maturity were calculated according to the following equation as described by Singhand Niwas (2015): 
$\mathrm{GDD}=($ Min. + Max. $) / 2-10$, where $\left(10.0^{\circ} \mathrm{C}=\right.$ base temperature $)$

\section{B - Vegetative growth:-}

\section{B.1. Date and percentage of vegetative bud opening:}

Date of vegetative bud opening was determined when a bud showed the first sign of opening (bud burst).Opening percentage of vegetative buds (as a percentage of total number of vegetative buds) was determined 30 days after bud burst stage.

\section{B.2. Shoot length:}

Shoot length was measured at the end of the growing season (December).

\section{C- Flowering and fruiting:}

\section{C.1. Percentage of flower bud opening:}

Percentage of flower bud opening was recorded and determined the completion of flowering (Full bloom) on 25 shoots / tree of each treatment and cultivar and calculated as follows:-

Percentage of flower bud opening $=\frac{\text { Number of opened flower buds }}{\text { Total number of flower buds }} \times 1001$

It should be pointed out that total number of flower buds was counted when buds took the dome shape.

\section{C.2. Dates of the different four stages of flower bud opening:}

Dates of the different four stages of flower bud development were recorded and correlated with heat units required to reach each stage. These stages are:

$$
\begin{aligned}
& \text { 1-Bud sweel } \\
& \text { 3-Petal fall f- Fruit set }
\end{aligned}
$$

\section{C.3. Fruit set percentage:}

Fruit set was determined by counting number of set fruits (after 30 days of full bloom). Percentage of fruit set was calculated as follows:-

$$
\text { Fruit set } \%=\frac{\text { Number of set fruit }}{\text { Total number of flowers at full bloom }} \times 1001
$$

\section{C.4.Yield:-}

The total number of fruits per tree was counted Yield weight was estimated by multiplying number of fruit $X$ average weight of fruitat harvest time of each treatment and cultivar,.

\section{C.5. Fruit properties:}

At harvest time of each treatment and cultivar, sample of 25 fruits per tree was taken for studying the following physical and chemical properties: 


\section{C.5.A. Physical properties:}

Weight, size, length and diameter of fruit were measured. Fruit firmness was measured with Effegl, penetrometer $11.1 \mathrm{~mm}$ diameter prob, Effigl, Alfonsing, Italy and expressed as Lb/inch².

\section{C.5.B. Chemical properties:-}

Total soluble solids in juice (T.S.S.) were measured with a hand referactometer.

Juice acidity was determined according to A.O.A.C., (1970) and calculated as gram anhydrous citric acid/100 ml. Juice.

\section{Determination of Universal; Thiourea; Hydrogen Cyanamide and Mineral Oil Residues :- \\ Extraction method:}

- Universal ; Thiourea ; Hydrogen cyanamide:-

It is extracted from plant material (fruit) with methanol. The methanol is evaporated from extract, the remaining water phase is extracted with n-hexane, after concentrating the solvent and the residue is determined by chromatography using sulfur - specific flame photometric detector (Lopez-Femandez et al., 2014).

\section{- Mineral oils :}

A procedure for the determination of mineral oils in edible oil has been fully developed. The procedure consists of using a sulphuric acid-impregnated silica gel (SAISG) glass column to eliminate the fat matter. A chemical combustion of the fatty acids takes place, while the mineral oils are not affecting by the sulphuric acid. The column is eluted with hexane using a vacuum pump and the final extract is concentrated and analyzed by gas chromatography (GC) with flame ionization detector (FID). (Wrona et. al. 2013).

\section{Recovery experiment:}

We do this experiment $\{$ table (1)\} for evaluation the method that we use. Take control samples and spike it by known amount of tested compound and analysis it by the mentioned method. Then calculated the concentration that was found relative to that added.

Table 1. Recovery percentages of Universal; Thiourea ; Hydrogen Cyanamide and Mineral oil Residues.

\begin{tabular}{|c|c|}
\hline Treatments & $\begin{array}{c}\text { Recovery } \\
\text { percentage }\end{array}$ \\
\hline Universal $5 \%$ & $70.0 \%$ \\
\hline Universal $6 \%$ & $70.0 \%$ \\
\hline Thiourea 1.5\% + mineral oil 1.5\% & $75.5 \%$ \\
\hline Duromix 1.0\%+ mineral oil 1.5\% & $72.0 \%$ \\
\hline CAPL2 & $92.0 \%$ \\
\hline
\end{tabular}




\section{Statistical analyses:-}

Experimental data were subjected to one way analysis of variance (ANOVA) and differences between means were separated using the (L.S.D.) at $5 \%$ level of probability using M-state software (Snedecor and Cochran, 1982).

\section{RESULTS AND DISCUSSION}

\section{3-1 Chilling requirement of vegetative and flower buds:-}

Available and estimated chill hours (C.H.) from dormancy until vegetative bud break took the pyramidal shape (table 2) and from dormancy till flower bud break took the dome shape (table 3) were accumulated 30.0 and 22.0 C.H. in 2014 and 2015 seasons respectively at or below $7.2{ }^{\circ} \mathrm{C}$ under different treatments of two cultivars.

At or below $10.0^{\circ} \mathrm{C}$, during the first season Hollywood plum trees treated with Universal at $5 \%$ and thiourea $1.5 \%+$ mineral oil $1.5 \%$ had the lowest chilling hours to reach vegetative and flower buds break (284.0 C.H.) followed by those treated with Universal at $6 \%$ and (Duromix $1.0 \%+$ mineral oil 1.5\%) which had $293.0 \mathrm{C} . \mathrm{H}$. to break vegetative and flower buds dormancy, while, trees treated with CAPL2 and control had 29.0C. H. to break vegetative and flower buds dormancy. On the other hand, Beauty plum trees treated with Universal 5\%; (Duromix 1.0\% + mineral oil $1.5 \%$ ) and CAPL2 had the lowest chilling hours had $284.0 \mathrm{C} . \mathrm{H}$. to reach vegetative and flower bud break.

At or below $15.0^{\circ} \mathrm{C}$, during the first season Hollywood plum trees treated with Universal at $5 \%$ and thiourea $1.5 \%+$ mineral oil $1.5 \%$ needed 1151.0 C.H. to break vegetative and flower buds, followed by (Universal at $6 \%$ ) and (Duromix 1.0\%+ mineral oil $1.5 \%$ ) which needed $1155.0 \mathrm{C} . \mathrm{H}$. to break vegetative and flower bud dormancy, while, untreated trees needed 1194.0 C.H. to break vegetative bud dormancy and 1185.0 C.H. to break flower dormancy. Meanwhile, Beauty plum trees treated with Universal at 5\%;Duromix $1.0 \%+$ mineral oil $1.5 \%$ and CAPL2 had the lowest chilling hours $1151.0 \mathrm{C} . \mathrm{H}$. to break vegetative and flower buds .On contrast, untreated trees needed 1194.0C.H.to break vegetative buds and $1184.0 \mathrm{C} . \mathrm{H}$ to break flower buds.

On the other hand, during the second season thiourea $1.5 \%+$ mineral oil 1.5 $\%$; Duromix $1.0 \%+$ mineral oil $1.5 \%$ and CAPL2 treatments on Hollywood trees were the most effective ones to break vegetative and flower buds which needed 1161.0 C.H. Meanwhile, Beauty trees with Duromix 1.0\% + mineral oil $1.5 \%$ and caple 2 had $1161.0 \mathrm{C} . \mathrm{H}$. to break vegetative bud dormancy. On the other hand, 
Universal at 5\% and Duromix $1.0 \%+$ mineral oil $1.5 \%$ and CAPL2 treatments needed $1161.0 \mathrm{C} . \mathrm{H}$. to break flower bud dormancy. On the contrary, untreated trees needed 1214 C.H. for Hollywood and 122.0 C.H. with Beauty cultivar to break vegetative bud break. While, Flower buds of the two cultivars need 1189.0 C.H.to break dormancy.

In this concern, Stadler et al., (1991) applied a rest- breaking agent hydrogen cyanamide to established trees of plum cultivars Gaviota, Santa rosa and Songold growing in marginal regions. Concentrations of 0.5 or $1.0 \%$ applied 4 or 6 weeks before expected full bloom generally gave earlier and more uniform bud break in all cultivars. Application of DNOC in late Dec. or early Jan. on apple caused earlier bud break (Saad 1993). Martin (2012) mentioned that estimated chill hours at 7.2 ${ }^{\circ}$ Crequired250 C.H. of Beauty and $300-400 \mathrm{C} . \mathrm{H}$. of Hollywood plum cultivars. Hydrogen cyanamide at $3 \%$ and Thiourea at $1.5 \%$ singly or in combination with mineral oil at 5\% were sprayed on Caninoapricot, in early February. It was found that thiourea followed Hydrogen cyanamide in enhancing (Eissa 2007). 
Table 2. Chilling hours at or below $7.2^{\circ} \mathrm{C}, 10.0^{\circ} \mathrm{C}$ or $15.0^{\circ} \mathrm{C}$ on vegetative buds of two plum cultivars under different treatments in 2014 and 2015 seasons.

\begin{tabular}{|c|c|c|c|c|c|c|c|c|c|c|c|c|c|c|c|c|}
\hline \multirow{4}{*}{ Treatments } & \multicolumn{8}{|c|}{ Hollywood } & \multicolumn{8}{|c|}{ Beauty } \\
\hline & \multicolumn{4}{|c|}{2014 season } & \multicolumn{4}{|c|}{2015 season } & \multicolumn{4}{|c|}{2014 season } & \multicolumn{4}{|c|}{2015 season } \\
\hline & \multirow{2}{*}{$\begin{array}{c}\text { Dates of } \\
\text { rest termination* }\end{array}$} & \multicolumn{3}{|c|}{ Chilling hours at or below } & \multirow{2}{*}{$\begin{array}{c}\text { Dates of } \\
\text { rest } \\
\text { termination * }\end{array}$} & \multicolumn{3}{|c|}{ Chilling hours at or below } & \multirow{2}{*}{$\begin{array}{c}\text { Dates of } \\
\text { rest } \\
\text { termination * }\end{array}$} & \multicolumn{3}{|c|}{ Chilling hours at or below } & \multirow{2}{*}{$\begin{array}{l}\text { Dates of rest } \\
\text { Termination * }\end{array}$} & \multicolumn{3}{|c|}{ Chilling hours at or below } \\
\hline & & $7.2^{\circ} \mathrm{C}$ & $10.0^{\circ} \mathrm{C}$ & $15.0^{\circ} \mathrm{C}$ & & $7.2^{\circ} \mathrm{C}$ & $10.0^{\circ} \mathrm{C}$ & $15.0^{\circ} \mathrm{C}$ & & $7.2^{\circ} \mathrm{C}$ & $10.0^{\circ} \mathrm{C}$ & $15.0^{\circ} \mathrm{C}$ & & $7.2^{\circ} \mathrm{C}$ & $10.0^{\circ} \mathrm{C}$ & $15.0^{\circ} \mathrm{C}$ \\
\hline Universal 5\% & Feb. 10 & 30.0 & 284.0 & 1151.0 & Feb.11 & 22 & 315 & 1163.0 & Feb. 10 & 30.0 & 284.0 & 1151.0 & Feb. 12 & 22.0 & 319.0 & 1167.0 \\
\hline Universal $6 \%$ & Feb.11 & 30.0 & 293.0 & 1155.0 & Feb.14 & 22 & 328 & 1169.0 & Feb. 11 & 30.0 & 293.0 & 1155.0 & Feb. 11 & 22.0 & 315.0 & 1163.0 \\
\hline $\begin{array}{c}\text { Thiourea } 1.5 \% \\
+ \text { mineral oil } \\
1.5 \%\end{array}$ & Feb. 10 & 30.0 & 284.0 & 1151.0 & Feb. 10 & 22 & 306 & 1161.0 & Feb. 11 & 30.0 & 293.0 & 1155.0 & Feb. 11 & 22.0 & 315.0 & 1163.0 \\
\hline $\begin{array}{c}\text { Duromix 1.0\%+ } \\
\text { mineral oil } \\
1.5 \% \\
\end{array}$ & Feb.11 & 30.0 & 293.0 & 1155.0 & Feb.10 & 22 & 306 & 1161.0 & Feb. 10 & 30.0 & 284.0 & 1151.0 & Feb. 10 & 22.0 & 306.0 & 1161.0 \\
\hline CAPL2 & Feb.12 & 30.0 & 299.0 & 1159.0 & Feb.10 & 22 & 306 & 1161.0 & Feb. 10 & 30.0 & 284.0 & 1151.0 & Feb. 10 & 22.0 & 306.0 & 1161.0 \\
\hline Control & Mar. 5 & 30.0 & 299.0 & 1194.0 & Mar.7 & 22 & 343 & 1214.0 & Mar. 6 & 30.0 & 299.0 & 1197.0 & Mar. 8 & 22.0 & 311.0 & 1220.0 \\
\hline
\end{tabular}

*Date of rest termination was determined when $50 \%$ vegetative buds took the pyramidal shape. 
Table 3. Chilling hours at or below 7.2 0c, $10.00 \mathrm{c}$ or 15.0 oc on flower buds of two plum cultivars under different treatments in 2014 and 2015 seasons.

\begin{tabular}{|c|c|c|c|c|c|c|c|c|c|c|c|c|c|c|c|c|}
\hline \multirow{4}{*}{ Treatments } & \multicolumn{8}{|c|}{ Hollywood } & \multicolumn{8}{|c|}{ Beauty } \\
\hline & \multicolumn{4}{|c|}{2014 season } & \multicolumn{4}{|c|}{2015 season } & \multicolumn{4}{|c|}{2014 season } & \multicolumn{4}{|c|}{2015 season } \\
\hline & \multirow{2}{*}{$\begin{array}{c}\text { Dates of } \\
\text { rest } \\
\text { termination * }\end{array}$} & \multicolumn{3}{|c|}{ Chilling hours at or below } & \multirow{2}{*}{$\begin{array}{c}\text { Dates of } \\
\text { rest termination } \\
* \\
\end{array}$} & \multicolumn{3}{|c|}{ Chilling hours at or below } & \multirow{2}{*}{$\begin{array}{l}\text { Dates of rest } \\
\text { termination * }\end{array}$} & \multicolumn{3}{|c|}{ Chilling hours at or below } & \multirow{2}{*}{$\begin{array}{c}\text { Dates of } \\
\text { rest } \\
\text { Termination * }\end{array}$} & \multicolumn{3}{|c|}{ Chilling hours at or below } \\
\hline & & $7.2^{\circ} \mathrm{C}$ & $10.0^{\circ} \mathrm{C}$ & $15.0^{\circ} \mathrm{C}$ & & $7.2^{\circ} \mathrm{C}$ & $10.0^{\circ} \mathrm{C}$ & $15.0^{\circ} \mathrm{C}$ & & $7.2^{\circ} \mathrm{C}$ & $10.0^{\circ} \mathrm{C}$ & $15.0^{\circ} \mathrm{C}$ & & $7.2^{\circ} \mathrm{C}$ & $10.0^{\circ} \mathrm{C}$ & $15.0^{\circ} \mathrm{C}$ \\
\hline Universal 5\% & Feb.10 & 30.0 & 284.0 & 1151.0 & Feb.11 & 22.0 & 315.0 & 1163.0 & Feb.10 & 30.0 & 284.0 & 1151.0 & Feb.10 & 22.0 & 319.0 & 1161.0 \\
\hline Universal $6 \%$ & Feb.11 & 30.0 & 293.0 & 1155.0 & Feb.14 & 22,0 & 328.0 & 1169.0 & Feb.11 & 30.0 & 293.0 & 1155.0 & Feb.11 & 22.0 & 315.0 & 1163.0 \\
\hline $\begin{array}{c}\text { Thiourea } \\
1.5 \%+ \\
\text { mineral oil } \\
1.5 \%\end{array}$ & Feb.10 & 30.0 & 284.0 & 1151.0 & Feb.10 & 22.0 & 306.0 & 1161.0 & Feb.11 & 30.0 & 293.0 & 1155.0 & Feb.11 & 22.0 & 315.0 & 1163.0 \\
\hline $\begin{array}{c}\text { Duromix } \\
1.0 \%+ \\
\text { mineral oil } \\
1.5 \% \\
\end{array}$ & Feb.11 & 30.0 & 293.0 & 1155.0 & Feb.10 & 22.0 & 306.0 & 1161.0 & Feb.10 & 30.0 & 284.0 & 1151.0 & Feb.10 & 22.0 & 306.0 & 1161.0 \\
\hline CAPL2 & Feb.12 & 30.0 & 299.0 & 1159.0 & Feb.10 & 22.0 & 306.0 & 1161.0 & Feb.10 & 30.0 & 284.0 & 1151.0 & Feb.10 & 22.0 & 306.0 & 1161.0 \\
\hline Control & Feb. 25 & 30.0 & 299.0 & 1185.0 & Feb. 25 & 22.0 & 331.0 & 1189.0 & Feb.26 & 30.0 & 299.0 & 1191.0 & Feb. 25 & 22.0 & 331.0 & 1289.0 \\
\hline
\end{tabular}

*Date of rest termination was determined when 50 \% Flower buds took the dome shape. 


\section{B. Dates of vegetative bud opening:-}

It is obvious from table (4) that all bud break agents applied under study started opening of vegetative bud [15-20] days approximately earlier than the control plants in this study. In this respect (Dennis, 1994) stated that dormancy actually ends when further chilling no longer effectively hastens bud break. However, once a critical number of chill units have been accumulated, heat units hasten bud break.

Table 4. Dates of vegetative bud opening of two plum cultivars under different treatments in 2014 and 2015 seasons.

\begin{tabular}{|c|c|c|c|c|}
\hline \multirow{2}{*}{ Treatments } & \multicolumn{2}{|c|}{ Hollywood } & \multicolumn{2}{c|}{ Beauty } \\
\cline { 2 - 5 } & 2014 & 2015 & 2014 & 2015 \\
\hline Universal 5\% & Feb. 21 & Feb. 22 & Feb.19 & Feb.20 \\
\hline Universal 6\% & Feb.20 & Feb.20 & Feb.21 & Feb.20 \\
\hline Thiourea 1.5\% + mineral oil 1.5\% & Feb.18 & Feb.21 & Feb.18 & Feb.16 \\
\hline Duromix 1.0\%+ mineral oil 1.5\% & Feb.20 & Feb.20 & Feb.17 & Feb.19 \\
\hline CAPL2 & Feb.21 & Feb.20 & Feb.21 & Feb.21 \\
\hline Control & Mar.5 & Mar.7 & Mar. 6 & Mar. 8 \\
\hline
\end{tabular}

Dates were determined when a bud showed the first sign of opening bud burst.

\section{C.) Opening percentages of vegetative and flower buds:}

Results in table (5) show the effect of different breaking agents under study on vegetative and flower bud opening percentages in the two seasons. Hollywood trees treated with Universal at 5\% ; Universal at 6\% and Duromix 1.0\% + mineral oil 1. 5\% had the highest significant vegetative buds opening percentage in the two seasons. Meanwhile, Beauty trees treated with Universal at $5 \%$; Universal at 6\%; thiourea $1.5 \%+$ mineral oil $1.5 \%$ and Duromix $1.0 \%+$ mineral oil $1.5 \%$ had the highest significant vegetative bud opening percentages in the first season. In the second season, trees treated with Universal at $5 \%$; Universal at 6\% and Duromix $1.0 \%+$ mineral oil $1.5 \%$ had the highest vegetative bud opening percentages. Moreover, Hollywood trees treated with Universal at 5\%; Universal at 6\%; thiourea $1.5 \%+$ mineral oil $1.5 \%$ and (Duromix $1.0 \%+$ mineral oil $1.5 \%$ ) had the significant flower bud opening in the two seasons. Meanwhile, Beauty trees treated with Universal at 5\%; Universal at $6 \%$; (thiourea $1.5 \%+$ mineral oil $1.5 \%$ ) and (Duromix $1.0 \%+$ mineral oil $1.5 \%$ ) had the highest flower bud opining percentages in the first season. In the second season, Universal at 5\%; Universal at 6\%; thiourea $1.5 \%+$ mineral oil 
1. $5 \%$; Duromix $1.0 \%+$ mineral oil $1.5 \%$ ) and CAPL2 had the highest significant flower bud opening percentage in the second season.

In this respect, Aly et al., (1998) stared that Appling Dormex at $2 \%$ to the tree of five plum cultivars, increased the percentages of floral and vegetative buds, shortened blooming period, increased the overlapping between cultivars except with Hollywood was which earlier than the other and increased fruit set percentage. Also, Essia (2007) reported that to spray 'Canino' apricot trees with Dormex at 3\%+ mineral oil at $5 \%$ to achieve highest percentage of flower buds.

Table 5. Opening percentage $*$ of vegetative and flower buds of two plum cultivars under different treatments in 2014 and 2015 seasons.

\begin{tabular}{|c|c|c|c|c|c|c|c|c|}
\hline \multirow{3}{*}{ Treatments } & \multicolumn{4}{|c|}{ Hollywood } & \multicolumn{4}{|c|}{ Beauty } \\
\hline & \multicolumn{2}{|c|}{$\begin{array}{l}\text { Vegetative buds } \\
\qquad \%) \\
\end{array}$} & \multicolumn{2}{|c|}{$\begin{array}{c}\text { Flower buds } \\
(\%) \\
\end{array}$} & \multicolumn{2}{|c|}{$\begin{array}{c}\text { Vegetative buds } \\
(\%)\end{array}$} & \multicolumn{2}{|c|}{$\begin{array}{c}\text { Flower buds } \\
(\%) \\
\end{array}$} \\
\hline & 2014 & 2015 & 2014 & 2015 & 2014 & 2015 & 2014 & 2015 \\
\hline Universal 5\% & $52.09 \mathrm{~A}$ & $59.5 \mathrm{~A}$ & $40.6 \mathrm{~A}$ & $46.4 \mathrm{~A}$ & $50.21 \mathrm{~A}$ & $62.3 \mathrm{~A}$ & $42.5 \mathrm{~A}$ & $49.3 \mathrm{~A}$ \\
\hline Universal $6 \%$ & $56.8 \mathrm{~A}$ & $61.7 \mathrm{~A}$ & $44.8 \mathrm{~A}$ & $49.3 \mathrm{~A}$ & $53.7 \mathrm{~A}$ & $64.9 \mathrm{~A}$ & $42.9 \mathrm{~A}$ & $50.2 \mathrm{~A}$ \\
\hline $\begin{array}{c}\text { Thiourea } 1.5 \%+\text { mineral oil } \\
1.5 \%\end{array}$ & $44.3 \mathrm{~B}$ & $48.3 \mathrm{~B}$ & $42.4 \mathrm{~A}$ & $43.5 \mathrm{~A}$ & $54.66 \mathrm{~A}$ & $51.7 \mathrm{~B}$ & $39.8 \mathrm{~A}$ & $44.5 \mathrm{~A}$ \\
\hline $\begin{array}{c}\text { Duromix } 1.0 \%+\text { mineral oil } \\
1.5 \%\end{array}$ & $54.26 \mathrm{~A}$ & $60.4 \mathrm{~A}$ & $43.8 \mathrm{~A}$ & $47.1 \mathrm{~A}$ & $52.4 \mathrm{~A}$ & $65.8 \mathrm{~A}$ & $40.5 \mathrm{~A}$ & $49.9 \mathrm{~A}$ \\
\hline CAPL2 & $18.43 \mathrm{C}$ & $24.3 \mathrm{C}$ & $33.9 \mathrm{~B}$ & $40.6 \mathrm{~B}$ & $22.13 \mathrm{~B}$ & $31.5 \mathrm{C}$ & $32.7 \mathrm{~B}$ & $45.1 \mathrm{~A}$ \\
\hline Control & $15.81 \mathrm{C}$ & $19.5 \mathrm{C}$ & $8.31 \mathrm{C}$ & $12.3 \mathrm{C}$ & $18.9 \mathrm{~B}$ & $23.6 \mathrm{D}$ & $9.6 \mathrm{C}$ & $13.7 \mathrm{~B}$ \\
\hline
\end{tabular}

Means in each column followed by the same letters are not significantly different at $5 \%$ level.

*Opening percentage of vegetative buds (as a percentage of total number of vegetative buds) was determined 30 days after bud burst stage.

*Opening percentage of flower bud was determined at full bloom.

\section{2) Vegetative growth:-}

\section{A. Shoot Length:-}

Data in table (6) obtained that Universal at $5 \%$ and CAPL2 treatments induce the highest shoot length of Hollywood cultivar in the two seasons. Universal at $5 \%$ and $6 \%$ gave the highest shoot length in the second season with Beauty cultivar. 
Table 6. Shoot length of two plum cultivars as affected by different treatments in 2014 and 2015 seasons.

\begin{tabular}{|c|c|c|c|c|}
\hline \multirow{3}{*}{ Treatments } & \multicolumn{4}{|c|}{ Shoot length $(\mathrm{cm})$} \\
\hline & \multicolumn{2}{|c|}{ Hollywood } & \multicolumn{2}{|c|}{ Beauty } \\
\hline & 2014 & 2015 & 2014 & 2015 \\
\hline Universal $5 \%$ & $42.23 \mathrm{~B}$ & $47.5 \mathrm{~A}$ & $36.67 \mathrm{BC}$ & $49.33 \mathrm{~A}$ \\
\hline Universal $6 \%$ & 31.67D & $32.67 \mathrm{CD}$ & $39.00 \mathrm{~B}$ & 47.67AB \\
\hline Thiourea $1.5 \%+$ mineral oil $1.5 \%$ & 31.33D & $37.00 \mathrm{C}$ & 30.33D & $26.33 \mathrm{D}$ \\
\hline Duromix $1.0 \%+$ mineral oil $1.5 \%$ & 30.33D & 30.67D & $33.33 \mathrm{CD}$ & $31.67 \mathrm{C}$ \\
\hline CAPL2 & $47.00 \mathrm{~A}$ & 43.33B & 48.67A & 43.33B \\
\hline Control & $37.67 \mathrm{C}$ & $15.00 \mathrm{E}$ & $36.67 \mathrm{BC}$ & $13.00 \mathrm{E}$ \\
\hline
\end{tabular}

Means in each column followed by same latters are not significant at $5 \%$ level.

\subsection{Flowering:-}

\section{A. Dates of flower bud opening:-}

It is obvious from tables $(7,8)$ that the greatest enhancement of complete flower stage was noticed with Duromix at $1.0 \%+$ mineral oil at $1.0 \%$ treatment Hollywood cultivar and thiourea at $1.5 \%+$ mineral oil at $1.5 \%$ treatment with Beauty cultivar, in the two seasons. Moreover, in fruit set stage Universal at 5\% ; Universal $6 \%$; Duromix at $1.0 \%+$ mineral oil at $1.0 \%$ and CAPL2 treatments resulted more earliness (20 days ) with Hollywood cultivar than the control plants. All treatments except CAPL2 treatment were earlier (20 days ) than control plants in the first season with Beauty cultivar. The same trend was observed in the second season; all treatments achieved 17-20 days earlier with Hollywood and ranged from 17-21 days earlier with Beauty cultivar compared to the control plants.

In this respect, Erez et al. (1993) stated that using Dinitro-0- Cresol in combination with oil was and still is used in Israel to break bud rest of deciduous fruit trees. Results in pome fruits (apple) showed that the combination of oil and $0.25 \%$ Cyanamide was very good for bud break. Also, Eissa (2007) studied the application of Dormex at $3 \%$ singly or in combination with light mineral oil at $5 \%$ on Canino Apricot. He found that it was most effective in advancing flower bud development stage. 
Table 7. Dates of different stages of flower bud opening and fruit set of two plum cultivars under different treatments in 2014 season.

\begin{tabular}{|c|c|c|c|c|c|c|c|c|}
\hline \multirow{2}{*}{ Treatments } & \multicolumn{4}{|c|}{ Hollywood } & \multicolumn{3}{c|}{ Beauty } \\
\cline { 2 - 9 } & $\begin{array}{c}\text { Bud } \\
\text { swell }\end{array}$ & $\begin{array}{c}\text { Complete } \\
\text { flowering }\end{array}$ & $\begin{array}{c}\text { petal } \\
\text { full }\end{array}$ & $\begin{array}{c}\text { Fruit } \\
\text { set }\end{array}$ & $\begin{array}{c}\text { Bud } \\
\text { swell }\end{array}$ & $\begin{array}{c}\text { Complete } \\
\text { flowering }\end{array}$ & $\begin{array}{c}\text { petal } \\
\text { full }\end{array}$ & Fruit set \\
\hline $\begin{array}{c}\text { Universal } \\
5 \%\end{array}$ & Feb.10 & Feb.26 & Feb.29 & Mar.5 & Feb.10 & Feb.27 & Feb.29 & Mar.5 \\
\hline $\begin{array}{c}\text { Universal } \\
6 \%\end{array}$ & Feb.11 & Feb.28 & Mar.3 & Mar.6 & Feb.11 & Feb.26 & Feb.28 & Mar.4 \\
\hline $\begin{array}{c}\text { Thiourea } \\
\text { mineral oil }\end{array}$ & Feb.10 & Feb.25 & Feb.28 & Mar.8 & Feb.11 & Feb.24 & Feb.28 & Mar.4 \\
\hline $\begin{array}{c}1.5 \% \\
\text { Duromix } \\
1.0 \%+ \\
\text { mineral oil } \\
1.5 \%\end{array}$ & Feb.11 & Feb.22 & Feb.25 & Mar.5 & Feb.10 & Feb.24 & Mar.1 & Mar.4 \\
\hline $\begin{array}{c}\text { CAPL2 } \\
\text { Control }\end{array}$ & Feb.25 & Mar.11 & Mar.13 & Mar.25 & Feb.26 & Mar.10 & Mar.12 & Mar.25 \\
\hline
\end{tabular}

Table 8. Dates of different stages of flower bud opening, petal full and fruit set of two plum cultivars under different treatments in 2015 season.

\begin{tabular}{|c|c|c|c|c|c|c|c|c|}
\hline \multirow[b]{2}{*}{ Treatments } & \multicolumn{4}{|c|}{ Hollywood } & \multicolumn{4}{|c|}{ Beauty } \\
\hline & $\begin{array}{l}\text { Bud } \\
\text { swell }\end{array}$ & $\begin{array}{l}\text { Complete } \\
\text { flowering }\end{array}$ & petal full & Fruit set & Bud swell & $\begin{array}{l}\text { Complete } \\
\text { flowering }\end{array}$ & petal full & Fruit set \\
\hline Universal 5\% & Feb.11 & Feb.28 & Mar.1 & Mar.5 & Feb.12 & Feb.27 & Mar.2. & Mar.4 \\
\hline Universal 6\% & Feb.14 & Feb.28 & Mar.1 & Mar. 5 & Feb.11 & Feb.26 & Feb.29 & Mar.4 \\
\hline $\begin{array}{c}\text { Thiourea } 1.5 \% \\
+ \text { mineral oil } \\
1.5 \%\end{array}$ & Feb.10 & Feb.25 & Feb.28 & Mar.8 & Feb.11 & Feb.23 & Feb.28 & Mar.4 \\
\hline $\begin{array}{c}\text { Duromix } \\
1.0 \%+\text { mineral } \\
\text { oil } 1.5 \% \\
\end{array}$ & Feb.10 & Feb.23 & Feb.27 & Mar.6 & Feb.10 & Feb.25 & Mar.1 & Mar.4 \\
\hline CAPL2 & Feb.10 & Feb.24 & Feb.28 & Mar.7 & Feb.10 & Feb. 25 & Feb.28 & Mar. 8 \\
\hline Control & Feb.25 & Mar.12 & Mar.14 & Mar.25 & Feb.25 & Mar.10 & Mar.13 & Mar.25 \\
\hline
\end{tabular}




\subsection{Fruiting:-}

\section{A. Fruit set Percentage:-}

Results in table (9) indicated that Universal $6 \%$ and Duromixat $1.0 \%+$ mineral oil at $1.5 \%$ treatments induced the highest significant fruit set percentages of Hollywood cultivar in the first season. But, in the second season Universal at 5\%; Universal at $6 \%$ and Duromix at $1.0 \%+$ mineral oil at $1.5 \%$ gave the highest significant fruit percentages.

Universal at 5\%; Universal at $6 \%$ and (Duromix at $1.0 \%+$ mineral oil at $1.5 \%)$ treatments gave the highest significant values in Beauty cultivar in the first season. But, in the second one Universal at 6\% andDuromix at $1.0 \%+$ mineral oil at $1.5 \%$ gave the highest fruit set Percentage.

From the above results, we notice that during the first season which had less recorded accumulation chilling units (at or below $10.00 \mathrm{C}$ and $15.00 \mathrm{C}$ ) with Hollywood and Beauty plum trees had less fruit set in comparison with the second season.

In this respect, El-Fakharani et al. (1994) stated that dormancy breaking agentson seven plum cultivars had a significant effect on the percentage of fruit set except with Hollywood according to date of application. However, Aly et al. (1998) who reported that the highest percentage of fruit set with Hollywood cultivar occurred with $1 \%$ Dormex. Also, Eissa (2007) recommended spraying "Canino" apricot trees with Dormex at 3\%+ mineral oil at $5 \%$ to achieve highest percentage of fruit set.

Table 9. Fruit set percentages of two plum cultivars as affected by different treatments in 2014 and 2015 seasons.

\begin{tabular}{|c|c|c|c|c|}
\hline \multirow{2}{*}{ Treatments } & \multicolumn{4}{|c|}{ Fruit set \% } \\
\cline { 2 - 5 } & \multicolumn{2}{|c|}{ Hollywood } & \multicolumn{2}{c|}{ Beauty } \\
\cline { 2 - 5 } & 2014 & 2015 & 2014 & 2015 \\
\hline Universal 5\% & $8.3 \mathrm{~B}$ & $9.9 \mathrm{~A}$ & $7.9 \mathrm{~A}$ & $9.5 \mathrm{~B}$ \\
\hline Universal 6\% & $9.6 \mathrm{~A}$ & $10.8 \mathrm{~A}$ & $8.4 \mathrm{~A}$ & $11.6 \mathrm{~A}$ \\
\hline Thiourea 1.5\% + mineral oil 1.5\% & $6.7 \mathrm{C}$ & $7.3 \mathrm{~B}$ & $6.2 \mathrm{~B}$ & $7.5 \mathrm{C}$ \\
\hline Duromix 1.0\%+ mineral oil 1.5\% & $9.9 \mathrm{~A}$ & $10.7 \mathrm{~A}$ & $8.2 \mathrm{~A}$ & $10.2 \mathrm{~A}$ \\
\hline CAPL2 & $6.8 \mathrm{C}$ & $7.4 \mathrm{~B}$ & $6.4 \mathrm{~B}$ & $7.7 \mathrm{C}$ \\
\hline Control & $6.3 \mathrm{C}$ & $6.4 \mathrm{~B}$ & $5.3 \mathrm{C}$ & $6.2 \mathrm{D}$ \\
\hline
\end{tabular}

Means in each column followed by same latters are not significant at $5 \%$ level.

\section{B. Heat requirements:-}

Data obtained in tables $(10,11,12,13)$ for 2014 and 2015seasonsindicated that the accumulated growing degree days from time of flower bud break till fruit maturity for all treatments were lower than the control. Universal 6\%treatment gave 
the lowest values 885.9 and $884.2 \mathrm{H} . \mathrm{u}$ in 2014 and 2015 seasons respectively with Hollywood Cultivar. On the other side,Duromixat $1.0 \%+$ mineral oil at $1.5 \%$, Universal at $5 \%$ and Universal at $6 \%$ treatments resulted in the lowest values $(915.5,904.3$ and $904.3 \mathrm{H}$. u. $)$ in the first season. Universal at 5\%, Universal at $6 \%$, Thioureaat $1.5 \%+$ mineral oil at $1.5 \%$ and Duromixat $1.0 \%+$ mineral oil at $1.5 \%$ treatmentsproduced the lowest values in the second season with Beauty cultivar.

Table 10. Heat units required for different stage of flower bud opening until fruit maturity of Hollywood cultivar as affected by different treatments in 2014 season.

\begin{tabular}{|c|c|c|c|c|c|c|c|c|c|}
\hline \multirow{2}{*}{ Treatments } & \multirow{2}{*}{$\begin{array}{c}\text { Date } \\
\text { of D.S. }\end{array}$} & $\begin{array}{c}\text { Complete } \\
\text { flowering }\end{array}$ & \multicolumn{2}{|c|}{ Petal fall } & \multicolumn{2}{c|}{ Fruit set } & \multicolumn{2}{c|}{ Maturity } \\
\cline { 3 - 13 } & & $\begin{array}{c}\text { after } \\
\text { D.S. }\end{array}$ & G.D.D & $\begin{array}{c}\text { Days } \\
\text { ffter } \\
\text { D.S. }\end{array}$ & G.D.D & $\begin{array}{c}\text { Days } \\
\text { after } \\
\text { D.S. }\end{array}$ & G.D.D & $\begin{array}{c}\text { Days } \\
\text { after } \\
\text { D.S. }\end{array}$ & G.D.D \\
\hline Universal 5\% & Feb.2 & 24 & 110.5 & 27 & 126.8 & 32 & 173.3 & 107 & 898.5 \\
\hline Universal 6\% & Feb.3 & 25 & 118.7 & 29 & 134.9 & 32 & 173.3 & 106 & 885.9 \\
\hline $\begin{array}{c}\text { Thiourea 1.5\%+ } \\
\text { mineral oil 1.5\% }\end{array}$ & Feb.1 & 24 & 110.5 & 27 & 126.8 & 36 & 199.5 & 111 & 915.8 \\
\hline $\begin{array}{c}\text { Duromix1.0\%+mineral } \\
\text { oil 1.5\% }\end{array}$ & Feb.1 & 21 & 98.8 & 24 & 110.5 & 33 & 175.9 & 108 & 904.3 \\
\hline CAPL2 & Feb.2 & 23 & 104.3 & 27 & 126.8 & 32 & 173.3 & 110 & 908.5 \\
\hline Control & Feb.13 & 27 & 126.8 & 29 & 134.9 & 41 & 229.9 & 117 & 1079.9 \\
\hline
\end{tabular}

D.S. =Dome shape of flower bud.

G.G.D = Growing degree day.

Table 11. Heat units required for different stage of flower bud opening until fruit maturity of Beauty cultivar as affected by different treatments in 2014 season.

\begin{tabular}{|c|c|c|c|c|c|c|c|c|c|}
\hline \multirow{2}{*}{ Treatments } & \multirow{2}{*}{$\begin{array}{c}\text { Date } \\
\text { of D.S. }\end{array}$} & $\begin{array}{c}\text { Complete } \\
\text { flowering }\end{array}$ & \multicolumn{2}{|c|}{ Petal fall } & \multicolumn{2}{c|}{ Fruit set } & \multicolumn{2}{c|}{ Maturity } \\
\cline { 3 - 13 } & & $\begin{array}{c}\text { Dafter } \\
\text { D.S. }\end{array}$ & G.D.D & $\begin{array}{c}\text { Days } \\
\text { after } \\
\text { D.S. }\end{array}$ & G.D.D & $\begin{array}{c}\text { Days } \\
\text { after } \\
\text { D.S. }\end{array}$ & G.D.D & $\begin{array}{c}\text { Days } \\
\text { after } \\
\text { D.S. }\end{array}$ & G.D.D \\
\hline Universal 5\% & Feb.1 & 26 & 121.4 & 28 & 129.4 & 33 & 175.9 & 108 & 904.3 \\
\hline Universal 6\% & Feb.1 & 25 & 118.7 & 27 & 126.8 & 32 & 173.3 & 108 & 904.3 \\
\hline $\begin{array}{c}\text { Thiourea 1.5\%+ } \\
\text { mineral oil 1.5\% }\end{array}$ & Feb.2 & 23 & 104.3 & 26 & 121.4 & 31 & 165.2 & 110 & 908.5 \\
\hline $\begin{array}{c}\text { Duromix1.0\%+mineral } \\
\text { oil 1.5\% }\end{array}$ & Feb.2 & 22 & 100.5 & 28 & 129.4 & 31 & 165.2 & 107 & 898.5 \\
\hline CAPL2 & Feb.1 & 25 & 118.7 & 28 & 129.4 & 32 & 173.3 & 111 & 915.5 \\
\hline Control & Feb.15 & 24 & 110.5 & 26 & 121.4 & 39 & 216.5 & 115 & 1056.4 \\
\hline
\end{tabular}

D.S. =Dome shape of flower bud.

G.G.D = Growing degree day. 
Table 12. Heat units required for different stage of flower bud opening until fruit maturity of Hollywood cultivar as affected by different treatments in 2015 season.

\begin{tabular}{|c|c|c|c|c|c|c|c|c|c|}
\hline \multirow[b]{2}{*}{ Treatments } & \multirow{2}{*}{$\begin{array}{l}\text { Date } \\
\text { of } \\
\text { D.S. }\end{array}$} & \multicolumn{2}{|c|}{$\begin{array}{l}\text { Complete } \\
\text { flowering }\end{array}$} & \multicolumn{2}{|c|}{ Petal fall } & \multicolumn{2}{|c|}{ Fruit set } & \multicolumn{2}{|c|}{ Maturity } \\
\hline & & $\begin{array}{l}\text { Days } \\
\text { after } \\
\text { D.S. }\end{array}$ & G.D.D & $\begin{array}{l}\text { Days } \\
\text { after } \\
\text { D.S. }\end{array}$ & G.D.D & $\begin{array}{l}\text { Days } \\
\text { after } \\
\text { D.S. }\end{array}$ & G.D.D & $\begin{array}{l}\text { Days } \\
\text { after } \\
\text { D.S. }\end{array}$ & G.D.D \\
\hline Universal $5 \%$ & Feb.1 & 27 & 127.9 & 33 & 167.2 & 43 & 191.2 & 110 & 890.3 \\
\hline Universal $6 \%$ & Feb. 3 & 26 & 122.8 & 27 & 127.9 & 31 & 145.3 & 108 & 884.2 \\
\hline $\begin{array}{l}\text { Thiourea } 1.5 \%+ \\
\text { mineral oil } 1.5 \%\end{array}$ & Feb.1 & 24 & 111.2 & 27 & 127.9 & 36 & 175.2 & 110 & 890.3 \\
\hline $\begin{array}{c}\text { Duromix } 1.0 \%+\text { mineral } \\
\text { oil } 1.5 \% \\
\end{array}$ & Feb.1 & 22 & 104.45 & 26 & 122.8 & 34 & 158.2 & 110 & 890.3 \\
\hline CAPL2 & Feb. 1 & 23 & 110.2 & 27 & 127.9 & 35 & 162.3 & 114 & 912.4 \\
\hline Control & Feb.6 & 35 & 174.8 & 37 & 184.7 & 48 & 214.3 & 127 & 1045.2 \\
\hline
\end{tabular}

D.S. =Dome shape of flower bud.

G.G.D $=$ Growing degree day.

Table 13. Heat units required for different stage of flower bud opening until fruit maturity of Beauty cultivar as affected by different treatments in 2015 season.

\begin{tabular}{|c|c|c|c|c|c|c|c|c|c|}
\hline \multirow[b]{2}{*}{ Treatments } & \multirow{2}{*}{$\begin{array}{c}\text { Date } \\
\text { of } \\
\text { D.S. }\end{array}$} & \multicolumn{2}{|c|}{$\begin{array}{l}\text { Complete } \\
\text { flowering }\end{array}$} & \multicolumn{2}{|c|}{ Petal fall } & \multicolumn{2}{|c|}{ Fruit set } & \multicolumn{2}{|c|}{ Maturity } \\
\hline & & $\begin{array}{l}\text { Days } \\
\text { after } \\
\text { D.S. }\end{array}$ & G.D.D & $\begin{array}{l}\text { Days } \\
\text { after } \\
\text { D.S. }\end{array}$ & G.D.D & $\begin{array}{l}\text { Days } \\
\text { after } \\
\text { D.S. }\end{array}$ & G.D.D & $\begin{array}{l}\text { Days } \\
\text { after } \\
\text { D.S. }\end{array}$ & G.D.D \\
\hline Universal 5\% & Feb.2 & 25 & 116.4 & 29 & 139.7 & 31 & 145.3 & 109 & 885.2 \\
\hline Universal 6\% & Feb. 1 & 25 & 116.4 & 28 & 132.4 & 32 & 169.5 & 110 & 890.3 \\
\hline $\begin{array}{l}\text { Thiourea } 1.5 \%+ \\
\text { mineral oil } 1.5 \%\end{array}$ & Feb.1 & 22 & 104.5 & 27 & 127.9 & 32 & 169.5 & 110 & 890.3 \\
\hline $\begin{array}{c}\text { Duromix } 1.0 \%+\text { mineral } \\
\text { oil } 1.5 \% \\
\end{array}$ & Feb.1 & 24 & 111.2 & 29 & 139.7 & 32 & 169.5 & 110 & 890.3 \\
\hline CAPL2 & Feb. 1 & 24 & 111.2 & 27 & 127.9 & 36 & 175.2 & 114 & 912.4 \\
\hline Control & Feb.6 & 33 & 174.2 & 36 & 175.2 & 48 & 214.3 & 127 & 1045.2 \\
\hline
\end{tabular}

D.S. =Dome shape of flower bud.

G.G.D = Growing degree day. 


\section{Dates of fruit maturity; harvest period and yield per tree:-}

Data in table (14) show the effect of different breaking agents under study on fruit number, yield weight per tree and dates of fruit maturity.

\section{1) Date of fruit maturity:-}

Different dormancy breaking treatments resulted in advancing date of fruit maturity. Application of Universal 5\%, Universal $6 \%$ and Duromix $1.0 \%+$ mineral oil $1.5 \%$ considered the best treatments in this aspect with the two cultivars and the two seasons. Moreover, all used breaking agents induce earlier maturity than the control by 17 to 21 days.

\section{2) Fruit number per tree:-}

Hollywood andBeauty tree treated with Universal 6\% treatment had the best significant fruit number in the two seasons compared with other treatments.

On thecontrary, Stadler et al., (1991) mentioned that hydrogen cyanamide at 0.5 or $1.0 \%$ did not significantly increase the number of fruits per tree of Gaviota plum cultivar.

\section{3) Yield weight per tree:-}

Hollywood and Beauty tree treated with Universal 6\% treatment had the highest significant yield weight per tree of Hollywood and Beautycvs.in the two seasons, compared with other treatments.

In this respect, El-wakeel et al., (1973) stated that spraying universal at 4\% increased yield on six plum varieties. Also, Bepete and Jackson (1993) sprayed hydrogen cyanamide at $1.5 \%$ on some apple cultivars. They found that it gave satisfactory bud break and flowering and gave heavy crops. Likewise, thiourea at $1 \%$ applied in spring time onSunbrite peach and Weinberger nectarine varieties increased the yield (kiiden et al., 1993), and kiwi fruit (Schuck and petri, 1995) concerning the positive effect of the application of various dormancy - breaking agents such as hydrogen cyanamide and thiourea whether singly or in combination with mineral oil enhancing yield, and improving fruit quality. 
Table 14. Dates of fruit maturity, harvest period and yield per tree of two plum cultivars as affected by different treatments in 2014 and 2015 seasons.

\begin{tabular}{|c|c|c|c|c|c|c|c|c|c|c|c|c|}
\hline \multirow{4}{*}{ Treatments } & \multicolumn{6}{|c|}{ Hollywood } & \multicolumn{6}{|c|}{ Beauty } \\
\hline & \multicolumn{3}{|c|}{2014 season } & \multicolumn{3}{|c|}{2015 season } & \multicolumn{3}{|c|}{2014 season } & \multicolumn{3}{|c|}{2015 season } \\
\hline & \multirow{2}{*}{$\begin{array}{c}\text { Dates of } \\
\text { fruit } \\
\text { maturity }\end{array}$} & \multicolumn{2}{|c|}{ Tree Yield } & \multirow{2}{*}{$\begin{array}{l}\text { Dates of } \\
\text { fruit } \\
\text { maturity }\end{array}$} & \multicolumn{2}{|c|}{ Tree Yield } & \multirow{2}{*}{$\begin{array}{c}\text { Dates of } \\
\text { fruit } \\
\text { maturity }\end{array}$} & \multicolumn{2}{|c|}{ Tree Yield } & \multirow{2}{*}{$\begin{array}{c}\text { Dates of } \\
\text { fruit } \\
\text { maturity }\end{array}$} & \multicolumn{2}{|c|}{ Tree Yield } \\
\hline & & $\begin{array}{c}\text { No. of } \\
\text { fruit }\end{array}$ & $\begin{array}{c}\text { Weight } \\
(\mathrm{kg})\end{array}$ & & $\begin{array}{c}\text { No. of } \\
\text { fruit }\end{array}$ & $\begin{array}{c}\text { Weight } \\
(\mathrm{kg})\end{array}$ & & $\begin{array}{l}\text { No. of } \\
\text { fruit }\end{array}$ & $\begin{array}{c}\text { Weight } \\
(\mathrm{kg})\end{array}$ & & No. of fruit & $\begin{array}{c}\text { Weight } \\
(\mathrm{kg})\end{array}$ \\
\hline Universal $5 \%$ & May 19 & $623.3 \mathrm{~B}$ & $11.80 \mathrm{C}$ & May 21 & $239.0 \mathrm{C}$ & $5.28 \mathrm{C}$ & May 19 & $854.0 \mathrm{~B}$ & $16.59 \mathrm{C}$ & May 21 & $227.7 \mathrm{C}$ & $6.14 C$ \\
\hline Universal $6 \%$ & May 19 & $955.0 \mathrm{~A}$ & $33.76 \mathrm{~A}$ & May21 & $522.7 \mathrm{~A}$ & $20.73 \mathrm{~A}$ & May 19 & 919.3A & $38.50 \mathrm{~A}$ & May 21 & $460.0 \mathrm{~A}$ & $18.00 \mathrm{~A}$ \\
\hline \begin{tabular}{|c|} 
Thiourea \\
$1.5 \%+$ \\
mineral oil \\
$1.5 \%$ \\
\end{tabular} & May 22 & $156.0 \mathrm{D}$ & $4.76 \mathrm{D}$ & May21 & 121.3D & 3.95D & May 22 & 152.7D & $5.06 \mathrm{D}$ & May 21 & 204.3D & $4.75 \mathrm{D}$ \\
\hline \begin{tabular}{|c|} 
Duromix \\
$1.0 \%+$ \\
mineral oil \\
$1.5 \%$ \\
\end{tabular} & May 19 & $415.3 \mathrm{C}$ & $15.58 \mathrm{~B}$ & May21 & $412.3 B$ & $14.34 \mathrm{~B}$ & May 19 & $507.0 \mathrm{C}$ & $27.65 B$ & May 21 & $412.3 \mathrm{~B}$ & $16.42 B$ \\
\hline CAPL2 & May 22 & $43.00 \mathrm{E}$ & $1.50 \mathrm{E}$ & May25 & 73.33E & 1.43E & May 22 & $59.33 \mathrm{E}$ & $2.91 \mathrm{E}$ & May 25 & $78.00 \mathrm{E}$ & $1.97 \mathrm{E}$ \\
\hline Control & June 9 & $23.33 \mathrm{~F}$ & $0.66 \mathrm{~F}$ & June 12 & $22.67 \mathrm{~F}$ & $0.56 \mathrm{~F}$ & May 9 & $39.67 \mathrm{~F}$ & $0.73 \mathrm{~F}$ & June 12 & $33.67 \mathrm{~F}$ & $0.62 \mathrm{~F}$ \\
\hline
\end{tabular}

Means in each column followed by same latters are not significant at $5 \%$ level.

\section{4.) Physical and Chemical properties of fruits:-}

Results in tables (15 and 16) indicated Duromix 1.0\%+ mineral oil $1.5 \%$ and Universal $6 \%$ treatments significantly increased the size, weight and diameter of fruits in the two cultivars in the two seasons compared to other treatments. However, Universal $5 \%$ and control treatments had the highest significant values in firmness with Hollywood cultivar in the two seasons. Meanwhile, control treatments achieved the highest firmness with Beauty cultivar. On the other hand, Duromix 1.0\%+ mineral oil $1.5 \%$ treatments in the first season, and Duromix $1.0 \%+$ mineral oil $1.5 \%$ and Universal $5 \%$ in the second one resulted in the longest fruit in Hollywood cultivar. Universal 6\%; Duromix 1.0\%+ mineral oil 1.5\% and CAPL2 in the first season, and Universal $5 \%$ and Universal $6 \%$ in the second one induced the longest fruit length in Beauty cultivar. With regard to T.S.S CAPL2 and Duromix 1.0\%+ mineral oil $1.5 \%$ treatments in the first season, and CAPL2 treatment only in the second onereduce the highest significant content of T.S.S with Hollywood cultivar. Meanwhile, Thiourea $1.5 \%+$ mineral oil $1.5 \%$ and Duromix $1.0 \%+$ mineral oil $1.5 \%$ in the two seasons with Beauty cultivar. With regard to acidity, control treatment induced the highest content of acidity in Hollywood cultivar. On the other hand control; (Thiourea 1.5\%+ mineral oil 1.5\%) and Duromix 1.0\%+ mineral oil 1.5\% treatments gave the highest acidity in Beauty cultivar.

In this respect, kiiden et al. (1993) mentioned that thiourea at $1 \%$ application affected the fruit quality positively and increased the fruit size. Also, Eissa (2007) stated that spraying 'Canino'apricot trees with Dormex at 3\% + meniral oil at 5\% achieved the highest fruit weight, volume and flesh thickness. 
Table 15. Physical and chemical properties of fruits of two plum cultivars under different treatments in 2014 season.

\begin{tabular}{|c|c|c|c|c|c|c|c|c|c|c|c|c|c|c|}
\hline \multirow{3}{*}{ Treatments } & \multicolumn{7}{|c|}{ Hollywood } & \multicolumn{7}{|c|}{ Beauty } \\
\hline & \multicolumn{5}{|c|}{ Fruit } & \multirow{2}{*}{$\begin{array}{l}\text { TSS } \\
(\%)\end{array}$} & \multirow{2}{*}{$\begin{array}{c}\text { Acidity } \\
(\%)\end{array}$} & \multicolumn{5}{|c|}{ Fruit } & \multirow{2}{*}{$\begin{array}{l}\text { TSS } \\
(\%)\end{array}$} & \multirow{2}{*}{$\begin{array}{c}\text { Acidity } \\
(\%)\end{array}$} \\
\hline & $\begin{array}{l}\text { Size } \\
(\mathrm{cm})\end{array}$ & $\begin{array}{c}\text { Weight } \\
\text { (gm) }\end{array}$ & $\begin{array}{l}\text { Length } \\
(\mathrm{cm})\end{array}$ & $\begin{array}{c}\text { Diameter } \\
(\mathrm{cm})\end{array}$ & $\begin{array}{l}\text { Firmness } \\
\left(\mathrm{lb} \backslash \text { inch }_{2}\right)\end{array}$ & & & $\begin{array}{l}\text { Size } \\
(\mathrm{cm})\end{array}$ & $\begin{array}{c}\text { Weight } \\
(\mathrm{gm})\end{array}$ & $\begin{array}{c}\text { Length } \\
(\mathrm{cm})\end{array}$ & $\begin{array}{c}\text { Diameter } \\
(\mathrm{cm})\end{array}$ & $\begin{array}{l}\text { Firmness } \\
\left(\mathrm{lb} \backslash \text { inch }_{2}\right)\end{array}$ & & \\
\hline Universal $5 \%$ & $16.38 \mathrm{D}$ & $18.52 \mathrm{~F}$ & 3.47D & $3.33 \mathrm{C}$ & $1.90 \mathrm{~A}$ & 8.17B & $0.59 \mathrm{E}$ & $21.77 \mathrm{E}$ & $19.24 \mathrm{~F}$ & $3.43 C$ & $3.53 \mathrm{BC}$ & $0.90 \mathrm{C}$ & $10.67 \mathrm{C}$ & $1.58 \mathrm{~B}$ \\
\hline Universal $6 \%$ & $34.48 \mathrm{~B}$ & $34.64 \mathrm{~B}$ & $3.80 \mathrm{C}$ & $4.33 \mathrm{~A}$ & $1.07 \mathrm{D}$ & $8.33 \mathrm{~B}$ & $1.38 \mathrm{CD}$ & $45.86 \mathrm{~B}$ & $47.38 \mathrm{~A}$ & $4.47 \mathrm{~A}$ & $3.97 \mathrm{~A}$ & $1.20 \mathrm{~B}$ & $10.83 \mathrm{C}$ & $0.75 \mathrm{D}$ \\
\hline Thiourea $1.5 \%+$ mineral oil $1.5 \%$ & $34.51 \mathrm{~B}$ & $31.49 \mathrm{D}$ & $4.10 \mathrm{AB}$ & 3.93B & $1.97 \mathrm{~A}$ & $7.67 \mathrm{C}$ & $1.30 \mathrm{D}$ & $24.03 \mathrm{D}$ & $34.73 \mathrm{D}$ & 4.07B & $3.53 \mathrm{BC}$ & $0.93 \mathrm{C}$ & $12.33 \mathrm{~A}$ & $2.19 \mathrm{~A}$ \\
\hline Duromix $1.0 \%+$ mineral oil $1.5 \%$ & $37.83 \mathrm{~A}$ & $36.84 \mathrm{~A}$ & $4.23 \mathrm{~A}$ & $4.43 \mathrm{~A}$ & $1.37 \mathrm{C}$ & $8.83 \mathrm{~A}$ & $1.51 \mathrm{~B}$ & $50.87 \mathrm{~A}$ & $45.83 \mathrm{~B}$ & $4.47 \mathrm{~A}$ & $3.73 B$ & $0.87 \mathrm{C}$ & $11.33 \mathrm{~B}$ & $1.97 \mathrm{~A}$ \\
\hline Control & $15.23 \mathrm{E}$ & $22.74 \mathrm{E}$ & $3.00 \mathrm{E}$ & 3.50 & $1.87 \mathrm{~A}$ & $7.67 \mathrm{C}$ & $2.26 \mathrm{~A}$ & $16.84 \mathrm{~F}$ & $22.57 \mathrm{E}$ & 3.03D & $3.40 \mathrm{C}$ & $1.87 \mathrm{~A}$ & 8.67D & $2.14 \mathrm{~A}$ \\
\hline
\end{tabular}

Mans in each column followed by same latters are not significant at $5 \%$ level.

Table 16. Physical and chemical properties of fruits of two plum cultivars under different treatments in 2015 season.

\begin{tabular}{|c|c|c|c|c|c|c|c|c|c|c|c|c|c|c|}
\hline \multirow{3}{*}{ Treatments } & \multicolumn{7}{|c|}{ Hollywood } & \multicolumn{7}{|c|}{ Beauty } \\
\hline & \multicolumn{5}{|c|}{ Fruit } & \multirow{2}{*}{$\begin{array}{l}\text { TSS } \\
(\%)\end{array}$} & \multirow{2}{*}{$\begin{array}{c}\text { Acidity } \\
(\%)\end{array}$} & \multicolumn{5}{|c|}{ Fruit } & \multirow{2}{*}{$\begin{array}{l}\text { TSS } \\
(\%)\end{array}$} & \multirow{2}{*}{$\begin{array}{c}\text { Acidity } \\
(\%)\end{array}$} \\
\hline & $\begin{array}{l}\text { Size } \\
(\mathrm{cm})\end{array}$ & $\begin{array}{c}\text { Weight } \\
\text { (gm) }\end{array}$ & $\begin{array}{l}\text { Length } \\
(\mathrm{cm})\end{array}$ & $\begin{array}{c}\text { Diameter } \\
(\mathrm{cm})\end{array}$ & $\begin{array}{l}\text { Firmness } \\
\left(\mathrm{Ib} \backslash \text { inch }_{2}\right)\end{array}$ & & & $\begin{array}{l}\text { Size } \\
(\mathrm{cm})\end{array}$ & $\begin{array}{l}\text { Weight } \\
\text { (gm) }\end{array}$ & $\begin{array}{l}\text { Length } \\
(\mathrm{cm})\end{array}$ & $\begin{array}{c}\text { Diameter } \\
(\mathrm{cm})\end{array}$ & $\begin{array}{l}\text { Firmness } \\
\left(\mathrm{lb} \mid \text { inch }_{2}\right)\end{array}$ & & \\
\hline Universal $5 \%$ & $23.28 \mathrm{E}$ & $25.84 \mathrm{C}$ & $3.47 \mathrm{C}$ & $3.37 \mathrm{C}$ & $2.27 \mathrm{~A}$ & $8.13 \mathrm{~B}$ & $0.68 \mathrm{D}$ & $28.88 \mathrm{C}$ & $28.20 \mathrm{C}$ & 3.73AB & $3.53 \mathrm{~B}$ & $0.50 \mathrm{D}$ & 11.67B & $1.52 \mathrm{~B}$ \\
\hline Universal $6 \%$ & $37.53 \mathrm{~A}$ & $38.32 \mathrm{~A}$ & $3.93 \mathrm{~A}$ & $4.43 \mathrm{~A}$ & $1.37 \mathrm{C}$ & 7.67CD & $1.19 \mathrm{C}$ & $31.26 \mathrm{~A}$ & $33.95 \mathrm{~A}$ & $3.77 \mathrm{~A}$ & $3.83 \mathrm{~A}$ & $1.20 \mathrm{~B}$ & $11.33 \mathrm{C}$ & $0.81 \mathrm{D}$ \\
\hline Thiourea $1.5 \%+$ mineral oil $1.5 \%$ & $30.94 \mathrm{~B}$ & $26.40 \mathrm{C}$ & $3.40 \mathrm{C}$ & $3.90 \mathrm{~B}$ & $1.37 \mathrm{C}$ & $7.50 \mathrm{D}$ & $1.19 \mathrm{C}$ & $23.71 \mathrm{E}$ & $22.61 \mathrm{E}$ & $3.50 \mathrm{C}$ & $3.47 \mathrm{~B}$ & $0.87 \mathrm{C}$ & $12.17 \mathrm{~A}$ & $2.12 \mathrm{~A}$ \\
\hline Duromix $1.0 \%+$ mineral oil $1.5 \%$ & $25.85 \mathrm{C}$ & $33.74 \mathrm{~B}$ & $3.73 \mathrm{~B}$ & $4.47 \mathrm{~A}$ & $1.40 \mathrm{C}$ & $7.83 \mathrm{C}$ & $1.55 \mathrm{~B}$ & $30.56 \mathrm{~B}$ & $29.12 B$ & $3.53 B C$ & $3.87 \mathrm{~A}$ & $1.10 \mathrm{~B}$ & 10.67D & $1.95 \mathrm{~A}$ \\
\hline Control & $18.87 \mathrm{~F}$ & 22.27D & 3.03D & $3.40 \mathrm{C}$ & $1.87 \mathrm{~B}$ & $7.83 C$ & $2.03 \mathrm{~A}$ & $18.90 \mathrm{~F}$ & $21.61 \mathrm{~F}$ & 3.07D & $3.40 \mathrm{~B}$ & $1.83 \mathrm{~A}$ & $8.83 \mathrm{E}$ & $2.17 \mathrm{~A}$ \\
\hline
\end{tabular}

Means in each column followed by same latters are not significant at $5 \%$ level. 


\subsection{Determination of Universal ;Thiourea ; Hydrogen Cyanamide and Mineral Oil Residues :-}

The data tabulated in table (17) showed that no residues found in two seasons in all treatments, except mineral oil, It was found $0.001 \mathrm{Mg} / \mathrm{g}(\mathrm{ppm})$ in the first season while it didn't detect in the second season and these data is acceptable because the samples were taken to analysis after 110 days from application in each season in both cultivars. The control was taken to do Recovery to evaluate the method and chemicals. The data showed that Recovery percentages were $92 \%, 75.5 \%, 70$ \%and $72 \%$ for mineral oil, thiourea, universal and Hydrogen cyanamide, respectively. In this respect, Erez et al. (1993) using rest-breaking treatments such as Dinitro-OCresol that in combination with oil and cyanamide for improving the level of bud break and for advancing bloom and vegetative development. In pome fruits (apple) the combination of oil and $0.25 \%$ cyanamide were found to result in a very good bud break with no phytotoxic effects on flower buds. Meanwhile, krisanapook and Subhadrabandhu (1993) mentioned that high concentration of hydrogen cyanamide were toxic noticed by dried dead shoots. Thus, North (1993) indicated that cyanamide, a powerful rest - breaking agent on a range of fruit kinds, may replace DNOC/oil in the short-term but acute toxicity symptoms limit its medium - term acceptance. Attempts to reduce it concentration without compromising efficacy by the dual application of other agents has been investigated. Although oils have long been known as rest-breaking agents, new and registered oil products applied alone and in conjunction with other potential substances have shown promise.

Table 17. Residual effect of some breaking agents of two cultivars under study after 110 days of application in 2014 and 2015 seasons.

\begin{tabular}{|c|c|c|c|c|}
\hline \multirow{2}{*}{ Treatments } & \multicolumn{2}{|c|}{ Hollywood } & \multicolumn{2}{c|}{ Beauty } \\
\cline { 2 - 5 } & 2014 & 2015 & 2014 & 2015 \\
\hline Universal $5 \%$ & ND* & ND & ND & ND \\
\hline Universal $6 \%$ & ND & ND & ND & ND \\
\hline Thiourea $1.5 \%+$ mineral oil $1.5 \%$ & ND & ND & ND & ND \\
\hline Duromix $1.0 \%+$ mineral oil $1.5 \%$ & ND & ND & ND & ND \\
\hline CAPL2 & 0.001 & ND & ND & ND \\
\hline
\end{tabular}

*ND: non detectable

\section{CONCLUSION}

Finally we can conclude that Dinitro-O-Cresol at $6 \%$ and Duromix at $1 \%+$ Mineral oil at $1.5 \%$ application on Hollywood and Beauty cultivars were the best dormancy- breaking agents.Also, all tested compounds can be used safely 110 days after application. 


\section{REFERENCES}

1. Aly, M. M., Kabeel, H. and Eliwa, G. I. 1998. Effect of some dormancy breaking treatments on some plum cultivars in Giza and Kalyubia Governorates. J. Agric. Sci. Mansoura Univ. 23 (7): 3301-3316

2. A.O.A.C. 1970. Official method of analysis of the Association of Official Agricultural chemists Washington D. C., USA.

3. Bepete, M. and Jacksonse, J. E. 1993. Apple cultivar performance and response to a Chemical dormancy- breaking spray under (Marginal) winter- chilling conditions in Zimbabwe. ISHS symposium on temprate zone fruits in the tropics and subtropics [TZFTS]. May 22-26 Cairo- Egypt.

4. Dennis, F. G. Jr. 1994. Dormancy- What we know (and don't know). Hortscience 29 (11): 1249-1255.

5. Dwyer, L. M. and Steward, D. W. 1986. Leaf area development in field grown maize.Agron. J., 78:334-348

6. Eissa, $\mathrm{M} .(2007)$. Effect of Hydrogen cyanamide, $\mathrm{KNO}_{3}$, thiourea; mineral oil and urea sprays on flowering, yield, and quality of "Canino " Apricot . Egypt. J. Appl. Sci., 22 (7).

7. El-Fakharani, E. M.; Stino, G. R. and Mokhtar. 1994. Effect of Hydrogen cynamide on flowering, fruit set and quality of seven plum cvs. Egypt. J. Appl. Sci 9 (2) : 751-769.

8. El-wakeel, A. T.; Tawfik, M.; Abdel Aziz, E. and Abu Basha, S. 1973. studies on breaking the rest period of plum trees . 1-Effect of Universal oil spays on yield and fruit quality of six varieties. Agric. Res.Revi. March.vol.57

9. Erez, A.; Ringwald, S. and yablowitz, Z. 1993. New means to break bud rest and advance bloom in apple and peach. ISHS symposium on temperate zone fruits in the tropics and subtropics (TZFTS). May 22-26 Cairo - Egypt.

10. Gilreath P. R. and Buchaman, D. W. 1981. Rest prediction model for low chilling 'Sun Gold' Nectarine J. Amer. Soc. Hort. Sci. 1061 (4) 426 - 429.

11. Kiiden, A.B.; Kaska, N. and Kiiden, A. 1993. The effects of thiourea and potassium Nitrate + Thiourea treatments on the release from dormancy of peach and nectarines. ISHS symposium on temperate zone fruits in the tropics and subtropics [TZFTS]. May 22 - 26 Cairo - Egypt.

12. Krisanapook, K. and Subhadrabandhu, S. 1993. Induction of bud break in Apple trees that received insufficient chilling by hydrogen cyanamid. ISHS symposium on temperate zone fruits in the tropics and subtropics [TZFTS]. May 22-26 Cairo - Egypt. 
13. Lopez-Femandez, O. ; Rid-Otera, R.; cid, A.; Simal - Gandara, J. 2014. Combined determination and confirmation of ethylene thiourea and proplenthiourea residues in fruits at low levels of detection.Food Chemistry. Volume 145: 1002 - 1010.

14. Martin, O. 2012. Reliable fruit tree varieties for Santa Cruz county. New and Notes of the UCSC farm and Garden.Issue 132.

15. North, MR. M. 1993. New rest breaking agents for the control of delayed foliation of Apples. ISHS symposium on temperate zone fruits in the tropics and subtropics [TZFTS]. May 22-26 Cairo-Egypt.

16. Saad M. E. 1993. Studies on growth regulators and bud -scale removal effects on flower bud development in Apple.ISHS symposium on temperate zone fruits in the tropics and subtropics (TZFTS).May 22-26 Cairo - Egypt.

17. Schuck, E. and Petri, J. E. 1995. The effect of concentrations and application of hydrogen cyanamide on kiwifruit dormancy breaking. Acta Hort. 395: 177-184.

18. Shahin, B. A.; Bahlool, S. E. and Mokhtar. 1997. Dormancy breaking of ElDorado plum trees with some chemicals. J. Agric. Sci.MansouraUniv. 22 (11): $3887-3894$.

19. Sherman W. B. and Lyrene, P. M. 1989. 'FlordaStar' peach. Fruit crops Department, IFAS, University Florida, Gainesille.Hortscience 24 (2): 395.

20. Singh, M. and Niwas, R. 2015. Thermal time utilization of plum in semi Arid Region of Gangetic plain. Science Research 3 (1) : 19-24.

21. Snedecor, G. W. and Chochran, W. G. 1982. Statistical methods $7^{\text {th }}$ ed. Iowa state Univ. Press. Iowa, USA.

22. Stadler, J. D; North, M. S. and Lotze, G. F. A. 1991. Artificial rest-breaking of apricot and plum cultivars using hydrogen cyanamide.Southern African Society for Hort.S.. 1 (1):9-11.

23. Weinberger, J. H. 1950. Chilling requirements of peach varieties. Proc. Amer. Soc. Hor. Sci. 56:122-128

24. Wrona, M.; Pezo, D. and Nerin, C. 2013. Rapid analytical procdure for determination of mineral oils in edible oil GC-FID. Food Chem Dec 15;141 (4): 3993-9. 


\title{
در اسات على التزهير والإثمار والأثر المتبقي لبعض كاسرات السكون على صنفين برق
}

\author{
عزة إبراهيم محمد' هند عبد اللاه محمودץ \\ ا ـ معهر بحوث البساتين - مركز البحوث الزراعية. \\ r ـ المعدل المركزي للمبيدات - مركز البحوث الزراعية.
}

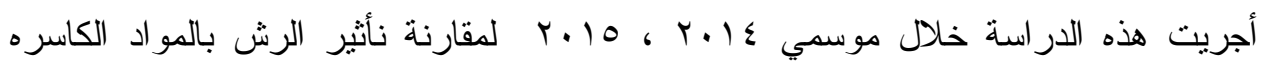

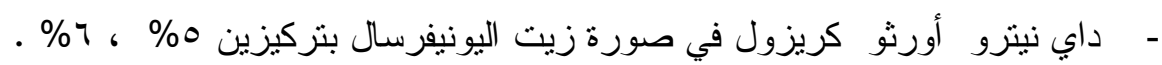

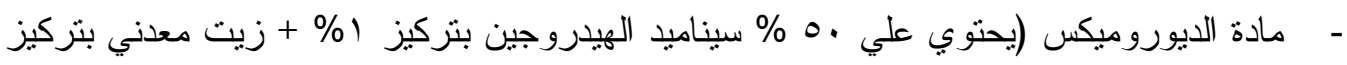

$$
\begin{aligned}
& \text { \% }
\end{aligned}
$$

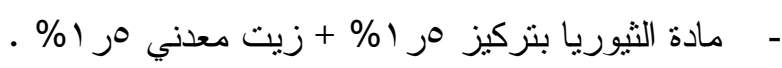

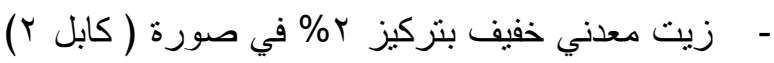

$$
\begin{aligned}
& \text { - - }
\end{aligned}
$$

وتم الرش بنالك المواد في منتصف يناير في الموسيمين وذللك لدراسة تأثيرها علي التزهير و الإاثمار وتحديد الآثر المتبقي من تلك المو اد الكاسرة للسكون على الثمار في صنفي برقوق

شملت القياسات إحتباجات البرودة - مو اعيد تقتح البر اعم - نسبة تقتح البر اعم الزهرية نسبة عقد الثمار - الإحتياجات الحرارية - مواعبد نضج الثمار - المحصول - الصفات

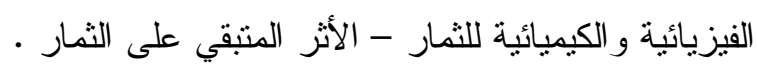

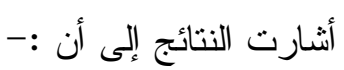

ساعات البرودة المتجمعة عند درجة حر ارة • 1 مُأو أقل كانت مناسبة أكثر من درجة

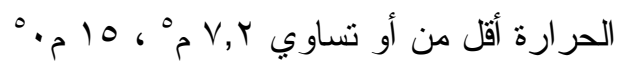

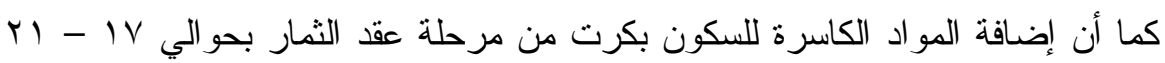

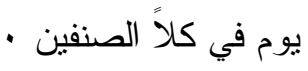

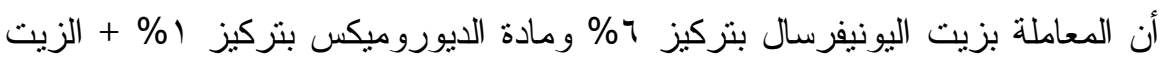

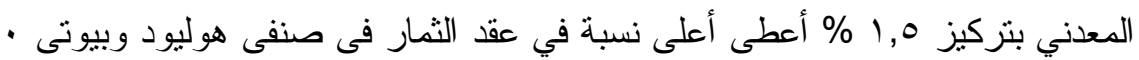

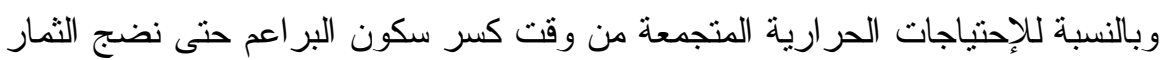

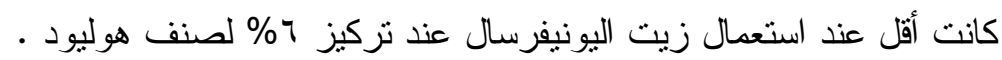

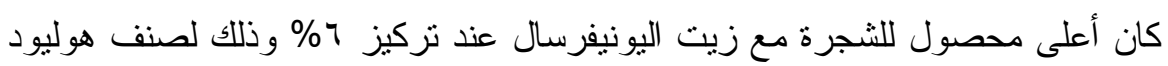


أدت المعاملة بزيت اليونيفرسال بكلا من التركيزين 0\% ، \% \% الى تبكير فى نضج الثمار

وبالنسبة لحجم ووزن وقطر الثمار كانت المعاملة بزيت اليونيفرسال عند تركيز ج\%

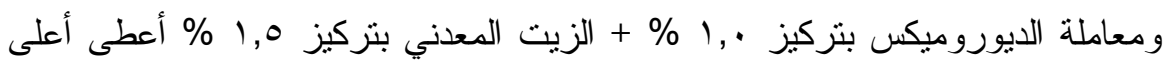

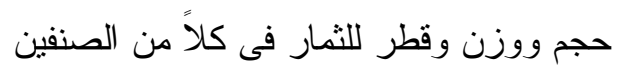
لا يوجد أثز سام متبقي لتلك المو اد الكاسرة للسكونفي الثمار جميعها وذلك بعد فترة

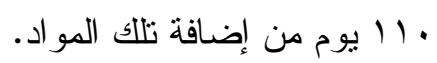

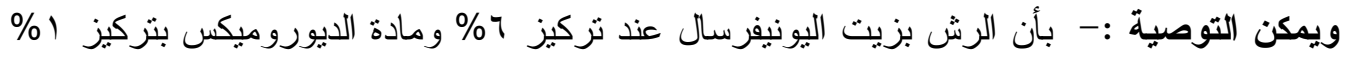

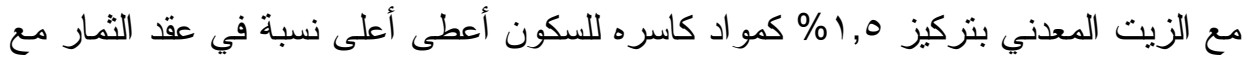

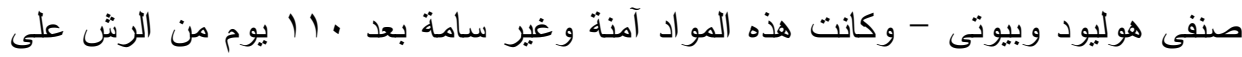

